\title{
Saint-Paul-Trois-Châteaux - 18 rue du Serre Blanc
} $\mathrm{n}^{\circ} 2211379$

\section{Christine Ronco}

\section{(2) OpenEdition}

\section{Journals}

Édition électronique

URL : http://journals.openedition.org/adlfi/14838

ISSN : 2114-0502

Éditeur

Ministère de la culture

Référence électronique

Christine Ronco, « Saint-Paul-Trois-Châteaux - 18 rue du Serre Blanc », ADLFI. Archéologie de la France - Informations [En ligne], Rhône-Alpes, mis en ligne le 20 mai 2015, consulté le 03 mai 2019. URL : http://journals.openedition.org/adlfi/14838

Ce document a été généré automatiquement le 3 mai 2019.

(C) Ministère de la Culture et de la Communication, CNRS 


\section{Saint-Paul-Trois-Châteaux - 18 rue du Serre Blanc}

$n^{\circ} 2211379$

\section{Christine Ronco}

Lien Atlas (MCC) :

http://atlas.patrimoines.culture.fr/atlas/trunk/index.php?

ap_theme=DOM_2.01.02\&ap_bbox=4.720;44.325;4.803;44.373

1 Le secteur diagnostiqué est situé au sud du lieu-dit les Sablières qui a livré plusieurs occupations antiques observées ou fouillées lors d'opérations antérieures. Ces occupations sont recouvertes par des niveaux sableux. La petite parcelle sondée correspond à une des deux parcelles exclues de la prescription du diagnostic réalisé en 2011. La stratigraphie est la même. Là encore, aucun vestige n'a été retrouvé.

INDEX

Index géographique : Rhône-Alpes, Drôme (26), Saint-Paul-Trois-Châteaux operation Opération préventive de diagnostic (OPD)

\section{AUTEURS}

\section{CHRISTINE RONCO}

Inrap 